SEVENTEENTH ANNUAL MEETING OF THE GEOLOGICAL SOCIETY OF AMERICA. By Eumund Otis Hovey.

THE seventeenth annual meeting of the Geological Society of America was held at the University of Pennsylvania, Philadelphia, December 29 to 31,1904 under the presidency of Prof. John C. Branner, of s of the science, were presented for read ing, and about one hundred members of the Society were in attendance, making the convention one of the largest in its history. The report of the Council for the year 1904 shows that in all respects the affairs of the Society are in a highly satisfactory condition The net active membership of the Society was reported Philadelphia, and 15 new members were elected at the bers have been removed by death: Prof. C. E. Beecher, J. B. Hatcher, Henry McCalley, W. H. Pettee, and Charles Schäffer. Memorials of these members were read at the first session of the Philadelphia meeting. Prof. Branner chose as the subject of his presiden the Northeast Coast of Brazil," and illustrated his paper by means of numerous photographs and charts. The most peculiar feature of this coast is the series of hardened sandspits, occurring at the mouths of most of the rivers. These spits consist of quartzose sand, which has been cemented together into a hard solid rock by means of calcium carbonate brought down in solution by the rivers and precipitated by contact with the waters of the ocean, which here possess a high
degree of salinity. This hardening extends to a depth of several feet and, in many instances, has been of of several feet and, in many instances, has been of great economic importance through the formation as at Pernambuco. The spits contain many fossils, al of which are of living spectes. A second coast feature nate or which are associated with the sandspits in certain localities. These reefs seem to be comparatively tain localities. These reefs seem to be comparatively
thin, but many of them are wide. That the coast has remained stationary for a considerable time, is indicated by the fact that these reefs reach to the upper dead coral within the fringe of living animals.

In the restricted space of a summary report like he present, it will not be possible to do more than briefly outline the contents of the more important of he 43 papers which were actually read, leaving out of title.

Dr. Robert Bell, director of the Geological Survey of Canada, read a somewhat detailed paper on the gake, and illustrated his remarks by maps and sections made for the Canadian Survey. Prof. E. R Cumings, of the Indiana State University, discussed the development and morphology of Fenestella, and
showed that this Devonian Bryozoa is related genetically to the Cyclostomata.

In a paper containing new evidences of the geograph ical differences of fossil faunas of the same age, Prof.
H. S. Williams, of Cornell University, stated that extended study of the Devonian rocks of the easter United States pointed to the conclusion that geologica faunas once thoroughly established probably possessed a geological range far greater than is indicated by the actual range in any particular section.

The petrographic and economic papers were intro-
duced by Prof. James F. Kemp, of Columbia University, in a paper detailing observations made along th garnet contact zones and associated copper ores at San José, Tamaulipas, Mexico. These contact zones are the result of the action of an intruded bed of andesite upon the surrounding Cretaceous limestone. Geologically the formation of garnets has been the most important feature, and has resulted from the rearrangement and recrystallization of the materials present in the lime stone. The chalcopyrite, which is the important ore, is a later phase of the contact phenomena. In another communication, Prof. Kemp described his method of "Geological Bookkeeping," which is a system of taking notes in the field, and of locating the observation invariably subdividing squares. This leads to a compilation book, in which the observations of scattered seasons are entered upon pages which correspond in their enumeration to the series of squares on the field tages in affording permanency and intelligibility of records, even though the latter be made at widely diverse times and by different individuals.

In a paper on the occurrence and distribution of celestite-bearing rocks, Dr. E. H. Kraus, of Michigan throughout central New York and southern California. The percolating waters have leached out the crystals to a considerable extent, forming the so-called "vermicular" limestones of New York and the "gashed" an "acicular" dolomites of Michigan. Precipitation of th material from these waters is the source of the large
deposits of celestite which occur at Put-in-Bay the Maybee Quarry, Monroe County, Michigan, and elsewhere.

Prof. T. C. Hoplins, of Syracuse University, de scribed the closely crystaliine, fine, fossiliferous, metamorphic limestones of central and southern California which contain the wonderful deposits of tourmalin and other gems which have been obtained within the past few years from Eldorado County southward to the national boundary.
According to Dr. G. P. Merrill, of the National Museum, the so-called asbestos (fibrous serpentine) of
the Thetford mines, Canada, and elsewhere, fills cavities which were made by the shrinkage of the massive serpentine, in which the fibrous material occurs, and he advanced arguments to prove that the filling process is due to
inward.

Messrs. Ralph Arnold and A. M. Strong, of the California State University, described at length the crystalline rocks of the San Gabriel Mountains near Pasadena, California. The last of the petrographical papers was by Dr. G. M. Murgoci, of Bucharest, Roumania, and concerned the origin of the peculiar kind of rock known as riebeckite granite, suggesting that the change from normal granite was due to heavy pressure combined with motion.

Five papers on physiographical geology were pre sented, three of which were read in full. Prof. N. M.
Fenneman, of the University of Wisconsin, in a paper on the control of the form of contact surfaces by marine denudation, laid down the principles that the rine denudation, laid a surface of unconformable contact between strata is determined by two factors: (1) the topogstrata is determined by two factors: (1) the topog-
raphy of the early land surface, and (2) cliff erosion raphy of the early land surface, and (2) cliff erosion
during submergence. The first element would preserve the former land surfaces in the subsequent beds, while the former land surfaces in the subsequent beds, while
the dominance of the second element would make the the dominance of the second element

Prof. R S. Tarr, of Cornell University, described Prof. R S. Tarr, of Cornell University, described
some drainage features of southern central New York, showing the relation of the pre-glacial valleys to the present surface. In many instances along the divide between the Susquehanna and St. Lawrence drainage system there is a condition of lowered divides, acros some of which, as in the Tioughnioga valley, east of
Cortland, and the Cayuta Creek valley, west and south of Van Etten, the present drainage passes. There are three theories to account for these phenomena: glacial erosion, erosion by ice-fed stream, and head-water eroion during rejuvenation. Evidence from valley form, lacial deposits, and hanging tributary valleys shows that these drainage features are in many cases, if not in all, due to changes of earlier date than the adof possible earlier ice advances, of which no evidence has been found in this region, is not eliminated, the acts so far discovered favor the hypothesis of reuvenation rather than of glacial action during earlier e advance.

The next paper pertained to hanging valleys, and was by Prof. Israel C. Russell, of the University of
Michigan. He recognizes four classes of such valleys, Michigan. He recognizes four classes of such valleys, considers that too much stress has been laid upon the existence of lateral glaciated hanging valleys on the sides of glaciated troughs, and he advances evidence to
show that in certain instances at least such valleys are show that in certain instances at least such valleys are
not due in a conspicuous manner to differentiation of glacial erosion. The study of glaciated hanging valleys is intimately connected with a still greater problem, namely, the origin of the leading features in
the relief of such mountains as the Sierra Nevada the relief of such mountains as the Sierra Nevada range and the Cascades. There is good reason for thinking that these two ranges were
sculptured prior to the glacial epoch.

Under the head of physical and structural geology
Undured prior to the glacial epoch. twelve papers were read. Prof. C. K. Leith, of the
University of Wisconsin, discussed in masterly fashion University of Wisconsin, discussed in masterly fashion the present state of knowledge of the subject of rock
cleavage, with special reference to recent publications by Dr. Becker and himself. The author has devised a piece of apparatus which mechanically illustrates his theories in a remarkable manner. Dr. E. H. Kraus, in a paper on the origin of the caves of the island of
Put-in Bay, Lake Erie, stated that in all probability Put-in Bay, Lake Erie, stated that in all probability re folding of the Lower Helderberg limestone of the deposits of due to hydration of anhydrite, since large wells in the immediate vicinity. The increase in vol ume caused by such hydration may be as high as 60 would be sufficient to argy developed in the process Subsequent leaching out of waters would account for the existence of the caves, and the collapse of the roofs of the cavities would account for the steplike form of the ceiling.

Mountain growth and mountain structure was the subject of a communication from Mr. Bailey Willis, of the United States Geological Survey. The study of eplains at various altitudes with reference to sea hat in North America and Eur-Asia, demonstrates from deformation, which produced warping of previously leveled-off surfaces. In general this process has been a recent one, post-Mesozoic in time, and it may
be held that mountains are youthful features of the earth. The structures which have been discovered in mountain masses are such as are developed under in the earth's mass. Study of the relation between structure and form leads to the conclusion that mod ern mountains are not the effects of the forces which foundation of older systems of classification.

Prof. Florence Bascom, of Bryn Mawr, brought out by means of detailed maps the nature of the formation and the structure of the Piedmont region of Pennsyl vania, giving the results of extended field work carried on for the United States Geological Survey. Her pape correlation with that of Pennsylvania, by Prof. E. B.
Mathews, of Johns Hopkins University. The latter author afterward read a paper on the Cockeysville close field study by himself and W. J. Miller, of Baltimore, into a concrete problem in Piedmont structure, miles, and lying north of the city of Baltimore. Mr. N. H. Darton, of the United States Geological Survey, in discussing overlap relations along the Rocky Mountain tront range, described features which have been traced by him through Wyoming and Colorado into New Mexico, mainly for the purpose of corre and Mesozoic rocks of the region present frequent variations in character, occurrence, and varieties. In the course of his field work, Mr. Darton visited the Zuñi salt lake, forty miles south of the Indian pueblo lar Zuni. At this locality there is in the plain a circular depression about a mile in diameter, containing a
salt lake and two cinder cones. The depth of the depression is about 200 feet, and its walls are of Creta-
pall pression is about 200 feet, and its walls are of Creta-
ceous sandstone, capped on one side by a lava flow. All ceous sandstone, capped on one side by a lava flow. All
around the rim there is a wide low ridge of volcanic around the rim there is a wide low ridge of volcanic
ejecta, which has been laid down in water. The history of this remarkable feature is not clear.

this remarkable feature is not clear.
Prof. Frank D. Adams, of McGill University, presented the results of an investigation made by himself and Mr. E. J. Coker into the cubic compressibility of rocks and certain phases of rock flow. The apparatus rocks and certain phases of rock flow. The apparatus
employed was an improvement of that which had been employed was an improvement of that which had been
used by Prof. Adams in some remarkable experiments, the results of which were published five years ago. In the present experiments, nickel-steel tubes have been used, and the compressibility of fourteen typical rocks
use present experiments, nickel-steel tubes have been determined. The deformation of the rock-making minerals concerned was carefully studied by means of the microscope.

Mr. E. Hovey, of the American Museum of Natural History, presented three papers upon the Caribbean Lucia as being the result of waning volcanic activity manifested along ancient fissures, but not within any manifested along ancient fissures, but not within any considered to be within an ancient broken-down crater, from the southern portion of which there was a super. ficial eruption of dust and fine lapilli in 1880. The tion of Mont Pelé, which was stated to be in a condition of intermittent mild activity; the dome, which tion of intermittent mild activity; the dome, which
has formed as a feature of the eruptions which began in 1902 , is still undergoing modifications, elevation and subsequent destruction by explosion being nearly
balanced. The great spine was destroyed more than a balanced.

year ago.

The six papers upon glacial geology which were read gave rise to much discussion. The first of the series
was by Prof. R. S. Tarr, upon the moraines of the was by Prof. R. S. Tarr, upon the moraines of the
Seneca and Cayuga Lake valleys. During the reces. sion of the Wisconsin ice sheet, a stand was made near the heads of the two lake valleys-Cayuga and Seneca. This major ice stand consisted of a series of minor halts in the receding ice, which projected lobes
up the two lake valleys, and minor lobes into the side valleys. By reason of the irregularity of topography and the several minor halts, a complex series of mo-
raines was accumulated, both as lateral and terminal raines was accumulated, both as lateral and terminal deposits, the latter being developed with especial in-
tensity in the two major valleys south of the heads of the lakes.

The drumlins in the Grand Traverse region of the northwestern part of the Southern Peninsula of Michigan have been studied recently by Mr. Frank Leverett, of Ann Arbor, Mich., who contributed a paper on them which, in the absence of the author, was read by Prof. Russell. Particular attention was devoted to modes of development, since more than one mode appears to have been operative; some drumlins have been sculptured from earlier deposits at the last ice advance, and some built up during that advance from material conto heavy deposits of nearly pebbleless laminated clay. apparently laid down in interglacial lakes, for this clay has been molded to some extent into drumlin forms by a subsequent ice invasion. Large valleys excavated in this interglacial clay were briefly disdrumlins, the latter being in some cases built upon
drused of the valley bottom.

A second paper upon the drumlin areas of Michigan was delivered by Prof. Russell. It described with scme detail two rezions in the Northern Peninsula of ous fean, in which drumlins form the most conspicucludes Les Cheneaux Islands and a part of the adjacent mainland, on the no:th shore of Lake Huron; and County, to the is situated principally in Menominee for the most part smooth-surfaced, half cigar-shaped hills of the normal type, but in a few instances instructive irregularities are present. Among these irreguelliptical ground-plan. as if a marginal portion of a well-shaped drumlin had been removed by erosion, leaving an abnormally steep slope; deep transverse trenches at right angles to their longer axes; straight. or curved trenches extending from their summits down their sides; irregular pits in their normally smooth surfaces; and, in one instance, a terrace-like shelf crest-line of the drumlin on the side of which it crest-line of the drumlin on the side of which it ocseveral eskers. From the evidence, the conclusion is 
arawn that the drumlins of the Menominee area were
produced by ice erosion from a previously deposited till sheet.

The drumlins of central New York State were the subject of a brief paper by Prof. H. L. Fairchild, of the University of Rochester, who also summarized the more important glacial problems in the State. A third paper by Prof. Fairchild took up the thesis that the theory of erosion by ice is a fallacy, in amplification of a paper presented by him at the preceding annual meeting of the Society. The author gave arguments for arriving at the conclusion that deep ice erosion of living rock has never been proven, and that it is practically impossible of accomplishment. In Ne has been no effective excavation by ice in the valleys of the Finger Lakes, the field study thus sustaining th theoretical consideration of the question.

The stratigraphical section of the programme showed the largest number of titles of papers offered an
read. Prof. W. G. Miller, of Toronto University, disread. Prof. W. G. Miller, of Toronto University, disTemiskaming, Ontario, not only from a stratigraphical Temiskaming, Ontario, not only from a stratigraphical
but also from an economic point of view. The region but also from an economic point of view. The region
in question shows at the base a complex assemblage of in question shows at the base a complex assemblage of
igneous rocks including granite. Erosion of this comigneous rocks including granite. Erosion of this com-
plex has given rise to conglomerate and finer-grained plex has given rise to conglomerate and finer-grained
slate-like rocks. Afterward ensued a second period of slate-like rocks. Afterward ensued a second period of
erosion, during which arkose and quartzite were deerosion, during which arkose and quartzite were de-
posited on the surface of the older two series. Finally posited on the surface of the older two series. Finally
each of these three series is intersected by dikes of each of these three series is intersected by dikes of
pre-Palæozoic age. The second group or series, the conglomerate and slate, is of economic interest on account of the occurrence therein of fissure veins carry ing important amounts of silver and of cobalt and rickel ores and smaller quantities of other ores.

In a paper on the palæogeography of St. Peter time Dr. C. P. Berkey, of Columbia University, showed by means of charts and sections the probable varying distribution of iand and water during the formation of the St. Peter sandstone of Minnesota. The rock
was interpreted as of marine origin where early deposwas interpreted as of marine origin where early depos-
ited. The region then became a land area, with the production of sand dune phenomena, after which there occurred another period of submergence. In the dis cussion which followed the reading of the paper, the fact was brought out by Prof. Gilbert van Ingen tha: rounded sand grains are not necessarily an indication rounded sand grains are not necessarily an indication
of arid conditions of deposition, since they are founc in coastal sand-dunes to-day. Dr. Berkey's second paper was upon the stratigraphy of the Uinta Moun-
tains, and announced the discovery of an erosion intertains, and announced the discovery of an erosion inter
val in the section, which favored referring the great val in the section, which favored referring the guartzite to Cambric age, rather than to Carbonic,

by Powell.
Prof. A. W. Grabau, of Columbia University, in a paper on the relative areas of the Oneida and Shawangunk conglomerates, advanced the theory that these
beds represent different portions of a basal conglomerate in the transgressing Siluric sea. In another paper, Prof. Grabau discussed Helderberg seas and the interrelationships of lower Devonic strata in the east-
ern United States. Charts were used in showing the ern United States. Charts were used in showing the
long narrow Cumberland sea, as this body of water is long narrow Cumberland sea, as this body of water is called. Mr. C. A. Hartnagel then, in some notes on the
Ontaric (Siluric) section of eastern New York, traced the comparative sections to the west and to the east of the Helderberg Mountains, and showed the continuous character of the Cobleskill beds. On the east the
formation immediately beneath this is, probably, Salina formation immediately beneath this is, probably, Salina in age, down to and through the Shawangunk cong

erate as the basal member of the Salina group.
The age of the Morrison formation of the Rocky Mountain region was the theme discussed by Mr. N. H. Darton, who has carried on extensive field work along the outcrops. It has been found that the Morrison formation is of wide extent in the Rocky Mountain region, from Montana to New Mexico, but evidence as occur, but the pare horizon, some investigators regarding them as Jurassic and others as late Cretaceous. The meager fresh-water molluscan fauna is not definitive. Some time ago, Mr. Willis T. Lee found evidence that Morrison shales give place to Comanche deposits in western Oklahoma, and the author has found similar relations in the Two Butte uplift in southeastern Colorado, and concludes that the Morrison strata are of Comanche (Lower Crethe Lakota and the Dakota sandstones of the Black Hills region.

In a paper on the classification of the Upper Cretaceous formations of New Jersey, Prof. Stuart Weller, by the State survey at various times, and, by means of fossils, substantiated the subdivision which had been made by Knapp and Kümmel on lithologic cuss in detail in a second paper the fauna of the cuss in detail in a second paper the fauna of the
Cliff wood, N. J., clays, which form the most notable example of marine sedimentation in New Jersey during Raritan time.

The fossils of Cook's Inlet and the Alaska Penin sula have been made the subject of careful study by Messrs. T. W. Stanton and G. C. Martin, of the United States Geological Survey. The section shows a great
thickness of beds, which are well provided with fossils. The beds seem to be closely related to the Jurassic strata of Russia. The scientific programme was closed by Prof. G. H. Perkins, of Vermont Univer-
sity, with a paper on the Tertiary lignite of Brandon,
Vermont, and its fossil fruits. These historic beds
were worked for fuel during the anthracite coal strike, and as a result many specimens of fossil fruits wer found, most of which are described now for the first time.

The officers of the Society for the ensuing year are: President, Raphael Pumpelly, of Dublin, N. H.; first vice-president, Samuel Calvin, of Iowa City, Ia.; secsecretary, H. L. Fairchild, of Rochester, N. Y.; treas urer, I. C. White, of Morgantown, W. Va.; editor,
J. Stanley-Brown, of New York city; and librarian H. P. Cushing, of Cleveland, $O$.

\section{IRRIGATION IN THE UNITED STATES}

The Bureau of the Census has just published a bulle States in 1902 . This report irrigation in the United resolution passed by the House at the first session of resolution passed by the House at the first session of
the Fifty-seventh Congress, and was prepared under the Fifty-seventh Congress, and was prepared under
the supervision of Mr. LeGrand Powers chief statisthe supervision of Mr. LeGrand Powers chief statis-
tician for agriculture, by Mr. Clarerrce J. Blanchard, tician for agriculture, by $\mathrm{Mr}$.
now of the Geological Survey.

The statistics presented were obtained by correspondence, supplemented by fieldwork in a few States and by information given by State engineers and their

The report is introduced by a short history showing the growth and development of irrigation in this counregions, by States, and by drainage basins.

During the last twenty years there has been an wakening to the opportunity that lies in the arid markable transformation has taken place in many parts of this region. Thousands of miles of canals, parts of this region. Thousands of miles of canals, representing a vast expenditure of money and labor and, which once was a barren desert but now is an ually producing crops worth $\$ 100,000,000$.

The remotest parts of our great desert are being reached by railroads, and the introduction of facilities for transportation has been followed by a correspond-
ing increase in irrigation. The irrigators, too, are becoming more experienced; their labors are less severe and their achievements are greater than those of their predecessors, because they have learned how to subdue and apply the forces of nature through innumer
able inventions. Problems of water storage and diable inventions. Problems of water storage and di-
version have been worked out to a practical solution. version have been worked out to a practical solution.
Every available stream is now a potent force for good. Every available stream is now a potent force for good.
The dams that hold back and store the floods also furnish abundant electric power for all purposes, and even the flow of the canals turns wheels that lift large quantities

With the development of irrigation the range sup ports larger herds and flocks, while in more than one valley the irrigation ditches have made possible the development of great mines. Populous and prosperous
cities have risen in the desert and have attained commercial and mercantile greatness

The statistics for 1902 show that 33,415 systems with 59,311 miles of main canals and ditches irrigated 9,487,077 acres on 134,036 farms. The amount expended in onstructing these systems was $\$ 93,320,452$.

The increase from 1899 to 1902 was more than 20 per cent for the number of irrigated farms, the number
of irrigated acres, and the construction cost of the systems.

The statistics are classified according to the three sources of water supply-streams, springs, and wells. The streams are by far the most important, since they supplied more than three-fourths of all the systems acreage.

While irrigation in all portions of the United States is for the same general purpose, the degree of reof application differ widely in certain more or less welldefined regions.

In this report the United States is divided into the following regions: The arid region, comprising those States and Territories between the western boundary of the Mississippi valley and the Pacific Coast, where tificial application of water to the land; the semiarid region, comprising parts of those States lying midway Retween the Rocky Mountains and the Mississippl tion is wherein the rainfall is so uncertain that irrigapitation; the rice producing States, comprising parts of Texas and Louisiana and certain counties in the Carolinas and Georgia; and the humid States, represented by several of the New England, Middle Atlantic, and Gulf Sta

The report shows that in 1902 there were in the arid region 91.1 per cent of the total number of irrigated farms, 89.3 per cent of the irrigated acreage, and 83 per cent of the construction cost of the systems. Althe arid region, the rate of increase from 1899 to 1902 was less for that region than for any other. In irrigated acreage the increase was 16.6 per cent for the arid region, 52.6 per cent for the semi-arid States and Territories, 76.2 per cent for the humid States, and 141.3 per cent for the rice States.

Of the nine States and two Territories in the arid region, California ranked first in both the number of systems; Utah ranked second in the number of farms, and third in the construction cust; and Colorado ranked third in the number of farms and second in the construction cost. In total irrigated area, Colorado For the arid region second; and Montana, third. per acre was $\$ 9.14$, and the average per irrigation system was $\$ 2,710$

For the semi-arid region as a whole, it may be said that ordinary crops can not be grown more than three years out of five without the artificial application of fertile as any in the United States, and with sufficient moisture produces large yields of any crop suited to rigated farms increased from region the number of ir1902 , or 43.4 per cent, while there was a gain of $\$ 2,212$,947, or 76.5 per cent, in the construction cost of sys-
tems. The largest relative increase was shown for North Dakota. In this region Nebraska ranked first and Texas second in the extent of irrigation.

Although rice is grown in nearly all of the Southern States, the practice of irrigation in its culture is confined principally to the coast counties of the Carolinas and Georgia, to the Mississippi delta, and to the coastal prairies of Texas and Louisiana. These coastal prairies were considered to be fit only for grazing until experiments in 1897 proved the peculiar adaptability of the soil for rice culture. Then many farmers from the States of the Middle West went to this
country and engaged in the cultivation of rice. They introduced improved methods and modern machinery, and there was a wonderful development in this industry. Now thousands of acres are being irrigated an-

In Louisiana the year 1902 was a year of great ex-
tremes. The growing season was tremes. The growing season was marked by exces-
sive drought, while the season of harvest was one of great rainfall. The season of harvest was one of great rainfall. The increased number of pumping
plants drew so heavily upon the rivers and bayous in plants drew so heavily upon the rivers and bayous in
the prairie region that their levels were lowered and the prairie region that their levels were lowered and
salt water came up from the Gulf and caused considerable damage. In order to prevent a similar occurerable damage. In order to prevent a similar occur-
rence, dams costing many thousands of dollars have rence, dams costing many thousands of dollars have
been built or are being planned, and additional levees have been thrown up.

Irrigation in the humid States is practised largely
a Irrigation in the humid States is practised largely
as an insurance against the droughts that occur early in the growing season. In 1902 irrigation was reported from Maine, Massachusetts, Rhode Island, Connecticut, New York, New Jersey, Pennsylvania, Florida, Alaand in Pennsylvania it was confined principally to hay and in Pennsylvania it was confined principally to hay
meadows bordering on small streams. A few farmers reported the irrigation of vegetables and small fruits, and exceptionally large yields were obtained.

In the winter of 1894-95 nearly all of the large orange groves in Florida were destroyed by frost, and many of engage in truck farming. They used their irrigation plants in the new work and the yields were improved plants in the new work and the yields were improved rigation in truck farming was demonstrated in this way many farmers have installed plants that may be used for irrigation purposes when needed. In this a great variety of crops are irrigated, and the irrigation systems are among the most modern in the country.

The future development, of the arid and semi-arid country depends largely upon the volume of its streams
and the utilization of as large a proportion thereof as and the utilization of as large a proportion thereof as
possible, and, in order that a better knowledge may possible, and, in order that a better knowledge may
be had of the extent to which these waters are being be had of the extent to which these waters are being
used, the statistics are also presented by drainage basins.

The Mississippi River drainage basin ranks first in importance for irrigation. The Mississippi valley proper is a region of ample rainfall, but the great western tributaries of the river flow through land where irrithird of of the utmost importance, and almost onearid regions is supplied by the of the arid and semiof this drainage basin supplied 2,906,665 acres on 27,999 farms. Its 8,090 systems, with 20,135 miles of canals and ditches, cost $\$ 20,494,070$

The Great Interior basin includes the most desertlike part of the arid regions, and, except in isolated localities, agriculture without irrigation is impossible. Throughout this basin the demands of irrigation have exhausted the normal flow of all the streams, and in severely. Conservalion of the mountains, crops suffer the streams will have to be resorted to in order to al low more land to be irrigated.

The reports for this basin show 22,805 irrigated 324 and cost $\$ 10,505,530$. In this basin there were 8,027 miles of canals and ditches.

The Columbia River basin was third in importance on 1902 , with its 5,470 systems irrigating $1,288,935$ acres canals and ditches cost $\$ 10,767,664$.

The Colorade River, both in length-2,000 milesand extent of drainage area-approximately 225,000 square miles-is- one of the greatest rivers of the aric West. However, the discharge of the Colorado River
direct, is less than that of many of the small eastern rivers because of the extreme aridity of the country As a result of the canyon-like character of the ColAs a result of the canyon-like character of the Col-
orado Valley, there were only twenty systems supplied from the main stream. Practically all of the ir rigation is from systems heading near Yuma, Ariz. 